\title{
基礎底面と地盤との空隙が杭基礎の動性状に及ぼす影響
}

正会員 ○山本鎮男* 同関孝*同松永捷一*

\section{1. 序}

支持層に支持された杭基礎の基礎底面と地盤との間に 空隚が生ずることがよくいわ机ている。即ち，支持層よ り上部にある土が，地下水位の変動，王密，或るい柱， 振動等の原因により沈下を起し，杭基礎のみが原位置を 保つために，空隚が生ずるのである。その空嚐が起ると 当然, 基礎に対する土の反力が減少し, 杭基礎抒よび, 杭基礎上にある上部構造のロッキング振動数は低くなっ て来る。このように，当初，予想された基礎および上部 構造の振動特性が，この空幥のため比変化することは， 設計当初から考慮に入れておかね将ならぬ問題である。 一般に，このような現象は考学られているが，これを数 量的に確認した研究はないようである。本研究は，実験 を通じて，空仯が生じた場合の現象を数量的に把握し， その原因を追求しょうとするものである。

\section{2. 実 験}

実験体は平面図が図-1，断面図が図-3に示されている 上うに $1.2 \mathrm{~m} \times 1.8 \mathrm{~m} \times 1.0 \mathrm{~m}$ のコンクリートのブロッ

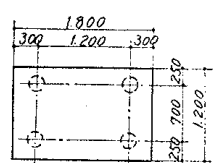

図-1

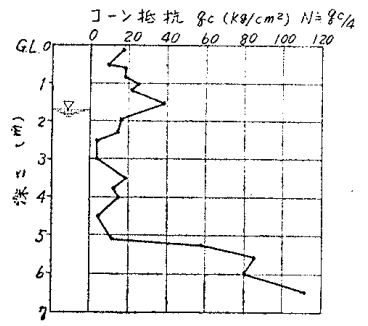

図-2

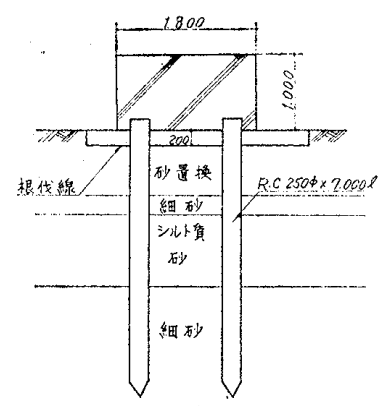

図-3
*千代田化工建設 $\mathrm{KK}$ ～** 綜合技術研究所貝

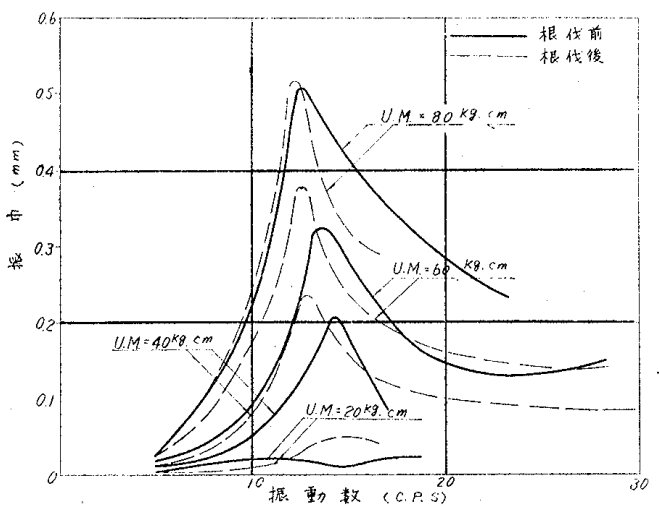

図-4

クで, 約 $N$ 值=30の畨に打ちこまれた鉄筋コンクリー 卜杭にて支持されている。地表層は䃯混りの不均一な地 整であるので表層 $1.7 \mathrm{~m}$ を砂にて置換した。加振方法 は，偏心モーメント式起振機を，ブロック上で，重心と 弾性主軸, 加振力の中心を一致せしめ, 長手方向に加振 した。図-4に，各実験種類にお打る共振曲線が描いてあ る。図中，根伐後とは，図-30根伐線に沿って，砂を根 伐り基䃈底面と地面との間に人工的に空隚を設けた時の 結果を示しており，根伐前の值と対比される。

\section{3. 考 察}

根伐前，根伐後の雨実験においても，アンバラス，モ ーメントの増大に伴い, 共振点が低い方に移行し, アン ダーリニャーな復元力特性を示している。アンバランス モーメント $20 \sim 40 \mathrm{~kg} / \mathrm{cm}$ では，明らかに根伐ったため に，復元力の低下が見られるが， $80 \mathrm{~kg} / \mathrm{cm}$ ではかなり 似かよった值を示している。

根伐後, 復元力が減少する原因としては, 基礎底面の 土との摩擦によって生ずる復元力，杭頭 $20 \mathrm{~cm}$ 分の側 面よりの復元力，および基礎のロッキング動による。地 盤よりの回転復元力が 0 になった等考えられる。根伐っ たことにより減少した復元力の追求は，根伐前における 杭と土との復元力の分担を追求することにもなる。 